\title{
Esclavitud y libertad en Cartagena de Indias. Reflexiones en torno a un caso de manumisión a finales del periodo colonial
}

\author{
Loredana Giolitto \\ Università degli Studi di Genova (Italia) \\ 260736@unige.it
}

\begin{abstract}
Resumen
A partir del estudio de las actas de un juicio iniciado por una esclava y su esposo contra la familia de su difunto amo y de las contraddicciones que emergen de los discursos de los contendientes, se desarrollan en este artículo unas reflexiones acerca de los fundamentos de la esclavitud y de la libertad en la sociedad cartagenera del período colonial tardío. El analisis se enfoca primero, sobre los aspectos jurídicos y sociales, evidenciando las dificultades de establecer distinciones precisas entre libertad y esclavitud y entre libres y esclavos, en una época de profundas transformaciones sociales. De las palabras de los contendientes emergen sin embargo concepciones ineditas de esclavitud y libertad. Estas ideas que se funcionalizan para definir la relación entre la esclava Rafaela y su amo y padre, recogen antiguos valores atados a la nobleza y al "derecho de sangre".

Palabras clave: ESCLAVITUD, LIBERTAD, MANUMISIÓN, CARTAGENA DE INDIAS, SIGLO XVIII.
\end{abstract}

\begin{abstract}
On the basis of the study of the proceedings of a trial started by a slave woman and her husband against the family of her dead master, and of the contradictions emerging from the litigants' declarations, this article intends to make some reflections on the foundations of slavery and freedom in the society of Cartagena in the late colonial time. The analysis focuses first on the juridical and social aspects, highlighting the difficulties in establishing, in an age of deep social transformations, clear-cut distinctions between slaves and free people. From the words of the litigants unexplored conceptions of slavery and freedom emerge. In order to define the relationship between the slave Rafaela and her master and father, old notions of blood bonds and aristocratic values are employed.
\end{abstract}

Key words: SLAVERY, LIBERTY, MANUMISSION, CARTAGENA DE INDIAS, 18TH CENTURY 
En los centros urbanos hispanoamericanos la esclavitud tuvo características muy peculiares debido al mayor contacto físico entre los amos y sus esclavos, a las frecuentes dificultades para percibir las diferencias entre esclavos y negros o mulatos libres, y a las mayores posibilidades de liberación existentes en la urbe. En este trabajo me propongo reflexionar sobre la esclavitud en Cartagena de Indias a partir de la historia de una esclava, Rafaela Martínez, quien aparece en un expediente enviado en 1769 a la Audiencia de Santafé. Allí se encuentra la causa procesal que la esclava había iniciado contra el hijo de su difunto amo, pues éste se negaba a reconocerle a ella y a sus dos hijos la libertad que les había sido concedida en el testamento paterno. El expediente, conservado en el Archivo General de la Nación de Bogotá, recoge las transcripciones de los debates y las sentencias emitidas en Cartagena y del debate y la sentencia que se produjeron en la consiguiente apelación que tuvo lugar en los tribunales de Santafé de Bogotá. La fecha del primer documento se remonta a 1758, año en que la madre de Rafaela por primera vez reclama la libertad de su hija. La fecha del último documento es de 1770 y corresponde a la sentencia emitida por el tribunal de la Audiencia de Santafé.

El expediente en sí no está completo, ya que después de 1770 la causa se transfirió a la administración judicial de Cartagena y hasta ahora no me ha sido posible encontrar otros documentos referidos al caso. No obstante, las actas de las que dispongo revelan una áspera pero interesante contienda en la cual las partes nos suministran interpretaciones inéditas de la esclavitud y de la relación amo-esclavo.

\section{La sociedad cartagenera en el siglo XVIII}

Para captar los rasgos de esta historia es necesario ubicarse en la ciudad en que tuvieron lugar: importante puerto negrero de los reinos españoles en las Américas y cruce comercial, de transacciones legales e ilegales y en la que coincidieron, unas veces en equilibrio y otras en conflicto, diversidad de personas, ideas y culturas provenientes de tres continentes.

A finales del siglo XVI y en la primera mitad del XVII Cartagena fue un puerto negrero muy importante. El monopolio comercial sobre la trata de esclavos, que ya se había venido resquebrajando con el contrabando, fue oficialmente abolido hacia 1778. Ese comercio tuvo un profundo impacto en su dinámica social: los esclavos eran retenidos por largo tiempo en la ciudad antes de ser vendidos y enviados a las tierras del Perú, Quito y Panamá. La facilidad con la cual la elite urbana los importaba y mantenía en gran número había cambiado radicalmente la composición de la población y había convertido a Cartagena en una ciudad "predominantemente negra y mulata". A finales del siglo XVIII la ciudad se distinguía por la liberalidad con la cual la administración de la justicia permitía la manumisión de los esclavos o

\footnotetext{
${ }^{1}$ Cfr. Alfonso Múnera, El fracaso de la nación. Región, clase y raza en el caribe colombiano (1717-1821) (Bogotá: Banco de la República; El Áncora Editores, 1998), 77-78. Ver además Alfonso Múnera, "Ilegalidad y frontera 17701800", en Adolfo Meisel, ed., Historia económica y social del Caribe colombiano (Bogotá: Ediciones Uninorte, 1994), 130; María del Carmen Borrego Pla, "La conformación de una sociedad mestiza en la época de los Austrias 1540-1700”, en Meisel, Historia económica, 101-102.
} 
les permitía cambiar de amo a causa de los maltratos, lo que provocaba con frecuencia la ira de la Audiencia de Santafé, capital del virreinato de Nueva Granada ${ }^{2}$.

La sociedad cartagenera había sido transformada por un largo proceso de mestizaje y por la emancipación de numerosos esclavos. La alta densidad de negros y mulatos -libres y esclavoshabía conformado un "ambiente" favorable a las diversas formas de manumisión, en relación a los esclavos empleados en el sector agrario o minero. Ya que los esclavos cartageneros no estaban relegados a los barrios o áreas periféricas, sino que residían en todo el espacio urbano, vivían al lado de las personas libres, participaban en los eventos de la ciudad y estaban presentes en todos los espacios de intercambio y circulación de ideas, informaciones y noticias. Las mujeres esclavas llenaban las calles de Cartagena vendiendo alimentos y los hombres se ofrecían como trabajadores jornaleros. La proximidad física entre amos y esclavos había influido positivamente en las manumisiones concedidas a estos últimos, mientras que el dinero ahorrado con el trabajo a jornal, había permitido a muchos de ellos adquirir la libertad ${ }^{3}$.

La mezcla racial había quebrantado las distinciones de raza de los primeros tiempos coloniales, amalgama de distinciones jerárquicas, típicas de la sociedad medieval castellana y de las dicotomías conquistador-conquistado y amo-esclavo, aplicadas a algunos rasgos somáticos de españoles, africanos e indios ${ }^{4}$. A finales del siglo XVIII el sector indio casi había desaparecido y habían surgido nuevos estratos sociales producto de las mezclas a lo largo de tres siglos ${ }^{5}$.

\footnotetext{
${ }^{2}$ La contrariedad de la Audiencia de Santafé emerge en estas palabras escritas en 1782: "Proposición a todas luces escandalosa la de ordenar la libertad o cambio de amo por mal trato de éstos y mucho más en Cartagena, donde los negros tienen acreditada su proterbia y que para contenerlos y exigirles un servicio regular es preciso mantener la mano levantada a cada paso y no dejarles pasar aún los defectos más leves". Jaime Jaramillo, "La sociedad neogranadina", en Ensayos de historia social (Bogotá: Tercer Mundo Editores, 1989), 55.

${ }^{3}$ Las posibilidades de liberación para los esclavos jornaleros fueron generalmente mayores respecto a las de los esclavos domésticos, cuyo destino dependía totalmente de la arbitrariedad de los amos. La vida de los jornaleros podía ser sin embargo muy dura y difícil: el dinero ganado se repartía de manera extremadamente inicua con el amo. Además el precio de la libertad no dependía del trabajo realizado por el esclavo, sino de la cantidad que el amo había pagado por él. Un esclavo que había costado mucho debía así trabajar mucho más que otro que había sido comprado por menor precio. Esto creó frecuentes y fuertes tensiones entre las exigencias de los amos y las reales posibilidades de ganancias para los esclavos. Cfr. Carmen Bernard, Negros esclavos y libres en las ciudades hispanoamericanas (Madrid: Fundación Histórica Tavera, 2000), 24.

${ }^{4}$ Cfr. Peter Wade, Race and Ethicity in Latin America (Londres: Pluto press, 1997), 6-7; Magnus Mörner, Race Mixture in the History of Latin America (Londres: Little, Brown and Company, 1967), 5; Antony Pagden, La caduta dell'uomo naturale. L'indiano d'America e le origini dell'etnologia comparata (Torino: Giulio Einaudi Editore, 1989), 29-33.

${ }^{5}$ En una carta dirigida al Consejo de Indias, el gobernador de Cartagena ilustraba, en el año 1751, la composición de la población de la ciudad: "Por el patrón de la Iglesia del corriente año de 1751 (aunque no se ha hecho con toda la prolixidad que yo deseaba) consta que esta ciudad, y el barrio de Gigimani en mil doscientos y doze casas contiene siete mil ochocientos cinquenta y seis personas de ambos sexos, de confesión, y comunión sin contar los oficiales, y soldados del Batallon de la Plaza, y que de las siete mil ochocientos cinquenta y seis personas, las seis mil cientos noventa y cuatro, es a saber, dos mil doscientos ochenta y ocho hombres, y tres mil nuevecientos y seis mujeres, son todos libres, componiendose este numero de blancos, negros, mulatos, zambos, y demas especies, con la prevención que la menor parte son blancos, y las restantes mil seiscientos sesenta y dos personas hasta el total de las siete milochocientos cinquenta y seis se componen de quinientos cinquenta y seis esclavos, y mil ciento y seis esclavas". "Expediente sobre el maltrato que dan los dueños de esclavos a estos en Cartagena y libertad en que dejan vivir a las
} 
Establecer confines entre una raza y otra se hacía difícil, las tensiones sociales aumentaban y la sociedad se cohibía, sin lograr impedir una siempre mayor evolución de sus miembros. La variedad de términos usados en aquel período para indicar los nuevos estratos sociales creados por el mestizaje (tercerones, cuartones, tente en el aire, salto atrás,...) bien representa la absurda intención de redefinir las diferencias de estatus que los cambios sociales habian hecho inciertos. Los criterios que hasta entonces habían determinado el complejo significado de raza, entraban en contradicción entre sí y podían impedir definir la colocación de una persona. En 1768 el promotor fiscal de la diócesis de Cartagena pedía al Consejo de las Indias aclaraciones de cómo clasificar las personas de "sangre mixta" en los registros de bautizo y matrimonio:

[...] hay libros de bautismo, y casamientos de españoles, blancos; y separadamente los hay para los negros, mulatos, cuarterones, mestizos. Sucede pues que un blanco español se casa con una negra, mulata, o mestiza. Los curas, como sabedores de su obligación ponen las partidas en los libros de mulatos. Llega el caso de que un hijo de estos quiere tomar estado: o que se muda de domicilio; y este o sus padres forman articulo, sobre que se traslade la fe de su bautismo al libro de los blancos. Unos se trasladan, y otros no ${ }^{6}$.

Si para el Consejo de Indias estaba claro que los hijos ilegítimos debían ser inscritos en los registros de las personas de "sangre mixta", para los hijos nacidos de uniones legítimas entre personas pertenecientes a razas diferentes surgían problemas relacionados con la contradicción existente entre su "naturaleza" y su situación legal:

[...] aunque es cierto, que los legítimos siguen la condición del padre, y que son nobles ó plebeyos según su diversa calidad, y que lo mismo sucede a su madre, que sigue igualmente la de su marido, dejando la propia que tenía antes de casarse; también lo es, que el mismo matrimonio, en que el padre comunica a su consorte e hijos la calidad propia de noble, ó plebeyo, como cabeza de esta pequeña sociedad en virtud de las disposiciones del derecho, no puede hacer, que deje de ser mulato el hijo legítimo de padre blanco, y de negra, porque no alcanza a tanto la ficción del derecho, que como imitadora de la naturaleza, no puede ir contra ella, ni hacer, que el consorcio conyugal vuelva blanca a la mujer que es negra ${ }^{7}$.

La respuesta del Consejo de Indias evidenciaba la confusión y la incertidumbre por definir la condición legal y social de los diferentes segmentos de la sociedad colonial. Por otro lado la "barrera del color" podía ser superada por aquellos que disponían de adecuados recursos

esclavas", Archivo General de Indias, Santa Fe, legajo 1023. Entre los hombres el 80\% eran por lo tanto libres y el $20 \%$ esclavos, entre las mujeres el $78 \%$ eran libres y el $22 \%$ esclavas. Según el censo efectuado en 1777 , la población, que había alcanzado 9532 habitantes estaba así compuesta: peninsulares $1 \%$, blancos $15 \%$, mulatos $63 \%$, negros $6 \%$, esclavos $15 \%$. Datos tomados de una tabla como apéndice al texto de Pablo Rodríguez, Sentimientos y vida familiar en el Nuevo Reino de Granada Siglo XVIII (Bogotá: Editorial Ariel, 1997).

6 “Baltasar Gómez de Liñan, promotor fiscal”. Archivo General de Indias, Santa Fe, legajo 1044.

${ }^{7}$ Ibídem. 
económicos. Si con anterioridad quien deseaba que fuera reconocida su condición de noble o limpio de sangre tenía que suministrar a las autoridades coloniales o españolas pruebas y testimonios de su estatus, en el siglo XVIII la Corona española concedía, a cambio de conspicuas sumas de dinero, no sólo toda suerte de títulos nobiliarios y de limpieza de sangre, sino también Cédulas de Gracias al Sacar, que permitían a negros y pardos ser reconocidos $\operatorname{como~blancos}^{8}$. La venta de estos títulos abría una profunda contradicción en el interior de la sociedad colonial: el hecho de que fuera posible adquirir títulos que certificaban una condición que presuponía ser natural y hereditaria, la privaba de los fundamentos sobre los cuales había sido construída.

Las crisis y las incertidumbres que afectaban a la sociedad cartagenera minaban también los fundamentos de la esclavitud, acentuando las contradicciones que desde siempre la habían caracterizado. Destinada a las personas de origen africano, la esclavitud americana había tenido una clara connotación racial, no obstante estaba regulada por el código castellano de las Siete Partidas, el mismo que no había concebido esta institución en términos raciales. La crisis de la sociedad colonial había hecho más incierta la relación entre la esclavitud, concebida como estatus jurídico, y la condición social del esclavo, fruto de distinciones estamentales y raciales. La percepción de libres y esclavos estaba cambiando lentamente y resultaba cada vez más difícil establecer un límite preciso entre libertad y esclavitud y entre libres y esclavos. Trataré de profundizar en estas cuestiones a través de la historia de la manumisión de Rafaela Martínez.

\section{Interpretaciones contradictorias de una cláusula ambigua}

Rafaela Martínez había nacido el 24 de octubre de 1733 en San Benito, un pequeño poblado de los alrededores de Cartagena, donde vivió por lo menos hasta los 36 años, cuando el tribunal de la Audiencia de Santafé emitió sentencia sobre su caso judicial. Había sido inscrita como hija legítima de dos esclavos, pero su verdadero padre había sido don Alberto Martínez, su amo. Antes de morir éste la había manumitido mediante una cláusula testamental que establecía que Rafaela debería servir a su mujer, doña Dionicia, hasta la muerte de ésta. La manumisión de Rafaela representaba probablemente el implícito reconocimiento de la paternidad de don Alberto, mientras la obligación de servir a Dionicia revelaba el deseo de garantizar cuidados y asistencia a la viuda, además de permitir que Rafaela, para entonces una joven de 16 años, pudiera continuar su educación. Rafaela, según los testigos interrogados en el curso del proceso, permaneció atada a Dionicia además por profundos lazos de afecto, ya que según declaran, Dionicia la había tratado siempre con consideración, cuidando de su educación y permitiéndole disfrutar de mucha libertad en la ejecución de los trabajos domésticos.

No obstante, en 1758, la madre de Rafaela, que años antes había sido vendida a otra ama y separada de su hija, declaraba ante la administración judicial que, en casa de doña Dionicia, su hija era maltratada por uno de los hijastros y pedía al teniente de gobernador, que toda vez que no existían obstáculos para la plena libertad de Rafaela, éste la alejara de la familia Martínez

\footnotetext{
${ }^{8}$ Cfr. Ramón M. Serrera, "Sociedad estamental y sistema colonial”, en Antonio Annino, Luis Castro Leiva, FrancoisXavier Guerra, De los imperios a las naciones, (Zaragoza: Ed. IberCaja, 1994), 63-64
} 
para que pudiera reunirse con ella en la ciudad. Sin embargo, a causa de la cláusula testamental, esta petición de la madre no pudo realizarse en este momento. Rafaela continuó pues viviendo en San Benito, y con el tiempo se casó con un negro libre llamado Lorenzo Gómez con el que tuvo dos hijos, que ella y su esposo consideraban libres.

Cuando la hija de Rafaela y Lorenzo, María Estanislaa, todavía no había cumplido cuatro años, Dionicia decide separarla de la madre y venderla como esclava a su hijo Miguel. Esta situación destroza las esperanzas de Lorenzo y Rafaela de poder en un futuro, vivir libres junto a sus hijos.

Miguel intentaba defender su derecho a comprar y retener como esclava a la hija de Rafaela y Lorenzo, argumentando que la condición jurídica de Rafaela no era la de libre, y por consiguiente tampoco lo eran sus hijos y que así sería hasta la muerte de Dionicia. En 1768 Lorenzo se dirige a la administración judicial para recuperar a la hija y lograr que Rafaela fuera declarada libre. La disputa entre Miguel Martínez y Lorenzo Gómez se centra en definir el significado de las condiciones que definían la claúsula de libertad de Rafaela en el testamento de su amo y padre.

Diez años antes, en 1758, el mismo Miguel Martínez, en su calidad de alcalde pedáneo, escribía una carta al teniente de gobernador en la que certificaba la existencia de la clausula de libertad de Rafaela en los siguientes términos:

Yo dicho alcalde habiendo registrado el testamento y he encontrado en él, la cláusula de la libertad de Rafaela en la cual dice que la deja por libre en la circunstancia que durante la vida de su legitima mujer haya de tener la obligación de servirle y llegado el caso de su fallecimiento de la dicha mujer, pueda libremente sin embarazo alguno gozar de su libertad ${ }^{9}$.

La cláusula contenida en el testamento de don Alberto era muy contradictoria. Por un lado afirmaba "dejar por libre" a Rafaela y que ésta podía "gozar" despúes de "su libertad", dando entender que ya era jurídicamente libre. Pero el término "servir", como estaba formulado en la cláusula, conservaba un significado ambiguo, adquirido en épocas precedentes, que permitía a don Miguel sostener que también la condición jurídica de Rafaela era todavía la de una esclava.

A partir de la tradición castellana medieval, el término servir había indicado el trabajo de los criados (servidores) y de los siervos (servidores y también esclavos) ${ }^{10}$. En la familia ibérica medieval criados y siervos, con frecuencia nacidos en la casa señorial, convivían con las

\footnotetext{
9 "De autos que ha seguido el negro Lorenzo Gómez con Don Miguel Martínez sobre libertad de su mujer Rafaela y dos hijos”, Archivo General de la Nación, Bogotá, Fondo Negros Esclavos de Bolívar, tomo 13, fl. 414.

${ }^{10}$ Véase la voz servir: "[...] hacer los ministerios pertenecientes a la persona, casa o hacienda de alguno, como criado o siervo suyo. Vale asimismo estar sujeto a otro por cualquier motivo, aunque sea voluntariamente, haciendo lo que él quiere, ó dispone”. Real Academia Española, Diccionario de autoridades (1737; Edición facsimil, Editorial Gredos, 1964).
} 
personas unidas por relaciones jerárquicas de parentesco y eran considerados de algún modo parte de la familia, por lo que se consideraba muy distinguido mantener en la propia casa a numerosos domésticos. Esta tradición había sido transmitida a la sociedad colonial, donde poseer un gran número de esclavos domésticos se había convertido en una necesidad "psicológica" de la elite que podía ostentar de esta forma sus caudales ${ }^{11}$.

A finales del siglo XVIII, el término servir no indicaba necesariamente una condición de esclavitud, ni de libertad, pero Miguel Martínez sostenía que la libertad era incompatible con cualquier forma de servicio obligatorio y sólo quien podía determinar sus propias acciones era libre. Si Rafaela hubiera sido formalmente libre, no estaría obligada a permanecer al servicio de Dionicia y podía marcharse en cualquier momento:

[...] la siniestra y repugnante interpretación que la cláusula se da, de ser la libertad en ella legada absoluta en lo formal, pues si tal fuera desde ahora pudiera pretenderla, sin esperar elemento de la muerte de mi madre, sin que lo impidiera el que titula material servicio, pues si la libertad fuera absoluta, aquel era voluntario ${ }^{12}$.

Miguel rechazaba distinguir la condición de facto de Rafaela por una hipotética y diferente condición jurídica, sino que interpretaba la libertad concedida a Rafaela como condicional, dependiente del servicio que ella habría tenido que prestar a Dionicia. La cláusula contenía una promesa de libertad, que sólo se concretaría después de la muerte de su ama:

[...] siendo su libertad [de Rafaela] condicional y no habiéndose verificado la muerte de mi madre contra quien esta demanda se dirije, y por la que, prestando voz y caución [...] respondo, no ha venido el día en que cese su cautiverio, a causa de que mientras mi dicha madre de su vida goce no puede la Rafaela dejar de estar a servidumbre sujeta, ni poseer lo que solicita, porque la condición puesta en cualquiera contrato o donación, siendo suspensiva como la presente, no surte efecto hasta que purificada pase a ser absoluta en tal conformidad, que lo prometido con ella, no se debe antes que exista ${ }^{13}$.

El lenguaje de don Miguel no es claro ni unívoco, ni para nosotros que lo leemos después de más de dos siglos, ni para los sujetos implicados en el asunto. Don Miguel no menciona la

\footnotetext{
${ }^{11}$ Las familias cartageneras más ricas poseían frecuentemente más de diez esclavos, que según el gobernador de la ciudad, además de no ser utilizados de manera provechosa, estaban expuestos a serios riesgos de epidemias: "[...]una familia ordinaria podría estar bien servida con cuatro esclavos, dos criados, y dos criadas, y la casa de mayor tratago con cuatro o seis esclavos, e igual número de esclavas; pero algunas familias (aunque pocas) tienen a grandeza el mantener todos los esclavos que nacen en la casa, sean de matrimonio, o fuera de él; habiendo casa que en onze esclavos y treze esclavas, casi todos haraganes, tienen un gran caudal inútil, expuesto a distintas enfermedades, pudiendo vender los que le sobran para trabajar en las haciendas[...]". "Expediente sobre el maltrato que dan los dueños de esclavos á estos en Cartagena y libertad en que dejan vivir á las esclavas”. Archivo General de Indias, Santa Fe, legajo 1023.

12 "De autos que ha seguido", fl. 419v, 420r.

${ }^{13}$ Ibídem, fl. 417r.
} 
palabra esclavitud. Por un lado, es posible deducir que atribuye a servidumbre el mismo significado de esclavitud; por el otro, puede ser intencionalmente ambiguo.

En una carta en que había escrito "[...] satisfaciendo al traslado que se me ha dado del escrito del negro Lorenzo Gómez en que pretiende se declare a Rafaela Antonia Martínez Calbo libre de actual servidumbre" ${ }^{, 4}$, Lorenzo había respondido:

[...] en mi pedimiento no he pretendido que la Rafaela mi esposa se separe del servicio de la Dionicia Calbo durante su vida como que por el Alberto Martínez su amo y padre la dejó a su fallecimiento con esta pención ${ }^{15}$.

En este y subsiguientes intercambios de escritos se percibe que además de sostener que Rafaela era todavía jurídicamente esclava, ya que así lo establecía la cláusula testamental, don Miguel trataba de anular toda diferencia entre quien era esclavo y quien sólo tenía la obligación de servir a otra persona: mientras que Dionicia se mantuviera con vida, Rafaela estaba obligada a permanecer a su servicio y no pudiendo disfrutar de las prerrogativas de una persona libre, permanecía esclava a todos los efectos.

Lorenzo y Rafaela, por su parte, sostenían que una condición de facto similar a la esclavitud no siempre coincidía con una condición jurídica de esclavitud: la obligación de servir a Dionicia no implicaba que Rafaela fuera formalmente esclava, ya que al morir don Alberto, ésta se había convertido jurídicamente en libre, aunque su libertad sería, todavía por algún tiempo, limitada por el servicio que debía cumplir.

Si el término servir podía ser malinterpretado, Lorenzo, al describir la condición de su mujer, prefería usar términos, como atender y cuidar, que tendían a excluir una relación de tipo esclavista y que evocaban más bien cuidado y asistencia ${ }^{16}$. La obligación de servirle prevista en la cláusula no indicaba por lo tanto una condición de esclavitud, ya que en el testamento, Alberto Martínez habría tenido que especificar si Rafaela permanecería esclava hasta la muerte de Dionicia. Por mano de su escribano, Lorenzo Gómez explicaba al teniente del gobernador que si Rafaela fuese todavía esclava, su esclavitud estaría restringida por dos razones: una de carácter "personal", ya que no podía servir sino a Dionicia, la otra de carácter temporal, ya que no estaba obligada a servir después de la muerte de Dionicia:

[...] la cláusula de libertad de mi esposa [...] en su entidad y en lo formal fue absoluta, y solo agravada en lo material del servicio durante la vida de su ama Madrasta, fuera de la cual a ninguna otra persona debe servir por previa obligación $^{17}$.

\footnotetext{
${ }^{14}$ Ibídem, fl. 416v.

${ }^{15}$ Ibídem, fl. 418v.

16 "Rafaela Atonia Martínez Calbo también libre, aunque con el gravamen de atender y cuidar por su vida a Dionicia Calbo". Ibídem, fl. 415v.

${ }^{17}$ Ibídem, fl. 418v.
} 
Por estos motivos Lorenzo subrayaba que, a diferencia de los esclavos, su mujer tampoco tenía un valor comercial.

¿Puede definirse como esclavitud algo tan delimitado? Responder a esta pregunta significa tratar de comprender quién era el esclavo en el derecho y en la sociedad cartagenera. En la América hispánica, la esclavitud fue reglamentada hasta finales del siglo XVIII, por el Corpus Juris de Justiniano, el Fuero Juzgo, de origen visigodo y por el código medieval de las Siete Partidas. Numerosas investigaciones ven dos motivos en la carencia de una legislación propiamente indiana sobre la esclavitud. Primero, las decisiones de naturaleza política, que privilegiaron la creación de un nuevo derecho público, desatendiendo la reforma del derecho privado. El otro, en la estructura jurídica casuística del derecho indiano, que indujo a los legisladores a producir, a menudo en situaciones de urgencia, leyes sobre la esclavitud de carácter predominantemente represivo y coyuntura $1^{18}$. El principal código de referencia para los juristas de la América hispánica fueron las Siete Partidas, pero cada vez que se revelaba insuficiente para resolver los casos en cuestión, era posible recurrir al derecho romano y germánico y a la costumbre.

En la legislación adoptada en las Indias, el esclavo no era simplemente una persona obligada a servir a otros, sino un sujeto con un estatus preciso, caracterizado por la falta de personalidad jurídica y definido por las relaciones de dominio y de patria potestad que lo ataban a su amo, que evidenciaban la naturaleza ambigua de persona y de cosa. Fernando de Trazegnies sostiene que para definir jurídicamente al esclavo es necesario analizar el núcleo social en que en la América colonial, como ya en la antigua Roma, fue colocado: la familia ${ }^{19}$. En este ámbito el esclavo estaba sujeto a la patriapotestas del señor (heredero del paterfamilias romano), junto a personas libres (mujer, hijos, nietos,...) y semi-libres. Las Siete Partidas describen así a los esclavos, entonces llamados siervos:

Siervos son otra manera de omes, que ha debdos, con aquellos, cuyos son, por razon del señorio, que han sobre ellos, Onde pues, que en el titulo ante deste, fablamos de los criados, que ome cria en su casa, que son libres: queremos aqui dezir de los siervos, porque son de casa ${ }^{20}$.

\footnotetext{
${ }^{18}$ Concepción García, "Sobre el ordenamiento jurídico de la esclavitud en las Indias Españolas", Anuario de historia del derecho español, no. 1 (1980): 1010; Manuel Lucena, Leyes para esclavos. El ordenamiento jurídico sobre la condición, tratamiento, defensa y represión de los esclavos en las colonias de la América española (Madrid: Fundación Histórica Tavera, 2000); Antonio Dougnac, Manual de historia del derecho indiano (México: Universidad Nacional Autónoma de México, 1994); Víctor Tau, Casuismo y sistema (Bueno Aires: Instituto de Investigaciones de Historia del Derecho, 1992); Enrique Gacto, Juan A. Alejandre, José M. García, El derecho histórico de los pueblos de España (Madrid: Agisa, 1988); Alan Watson, Slave Law in the Americas (Georgia: University of Georgia Press, 1989).

19 Fernando de Trazegnies, Ciriaco de Urtecho: litigante por amor. Reflexiones sobre la polivalencia del razonamiento jurídico (1981; Lima: Pontificia Universidad Católica del Perú, 1989), 103-105.

${ }^{20}$ Las siete partidas del sabio Rey don Alfonso X glosadas por Gregorio López (Salamanca: Andrea de Portonariis, 1555; edición facsimil, Madrid: Boletín oficial del Estado, 1974), partida quarta, tit. XXI.
} 
El ejercicio de un poder más fuerte sobre los esclavos, comparado con el que se ejercía sobre los hijos, no comportaba su reducción a meros objetos, ya que en el derecho romano y medieval los aspectos de persona y de cosa no fueron jamás distinguidos nitidamente y el esclavo no perdía la cualidad de persona por el mero hecho de ser cedido por el propio $a^{21}$. Persona hacía referencia al ser humano en términos físicos, tuviera o no personalidad jurídica, la cual era la capacidad de ser titular de derechos subjetivos y el estar obligado a cumplir deberes. Esos era los elementos que diferenciaban a los libres de los esclavos ${ }^{22}$.

Las Siete Partidas humanizaron la figura del esclavo, sin alterar sin embargo los fundamentos jurídicos de la esclavitud ${ }^{23}$. Aún afirmando el pleno dominio de los amos sobre los esclavos, establecieron límites. Los amos no podían matarlos, ni inflingirles heridas "contra natura", excepto en los casos de extrema gravedad (partida cuarta, tit. XXI, ley VI). Si el derecho romano había negado a los esclavos demandar a los amos, las Siete Partidas preveían que ellos podían denunciarlos por maltratos y, eventualmente, pedir que fueran vendidos a otras personas (partida cuarta, tit. XXI, ley VI). La posibilidad de contraer matrimonio llegó a ser, en las Siete Partidas, un derecho para los esclavos, a quienes les fue permitido casarse entre ellos o con personas libres, y aún contra la voluntad de los amos. No obstante, la carencia de personalidad jurídica permanecería en los siglos posteriores como el elemento diferenciador entre los esclavos y todas las otras categorías de personas.

Las Siete Partidas preveían algunas posibilidades de manumisión de los esclavos:

Libertad es poderio que ha todo ome naturalmente de fazer lo que quisiere solo, que fuerça: o derecho de ley, o de fuero, non gelo embargue. E puede dar esta libertad el señor a su siervo, en eglesia, o fuera della, o delante del juez: o en otra parte: $\mathrm{o}$ en testamento, o sin testamento, o por carta ${ }^{24}$.

La manumisión no confería sin embargo a los esclavos el mismo estatus que a las personas nacidas libres, sino la condición de liberto o de aforrado $^{25}$. La figura del liberto era ambigua, ya que a menudo el patrón (el ex-amo) conservaba sobre él algunos derechos, así como la obligación por parte del liberto de honrarlo, ayudarlo y socorrerlo, a él y a su familia (partida cuarta, tit. XXII, ley VIII y partida cuarta, tit. XXII, ley X). La condición de los esclavos manumitidos era además difícil de definir, ya que en la sociedad colonial, fueron previstas y realizadas manumisiones que aunque imponían al liberto servicios obligatorios, le concedían inmediatamente la libertad formal, y manumisiones condicionales, como la heredada del derecho romano, que confería al ex-esclavo la condición de statuliber. En este caso el amo

\footnotetext{
${ }^{21}$ De Trazegnies, Ciriaco, 105.

${ }^{22}$ Edoardo Voltera, Istituzioni di diritto privato romano (Roma: La Sapienza Editrice, 1985), 45-46 y 51-52.

${ }^{23}$ Alan Watson, Slave Law in the Americas (Georgia: University of Georgia Press, 1989), 46.

${ }^{24}$ Las siete partidas, partida quarta, tit. XXII, ley I.

25 "El estado delos omes e la condicion dellos, se departe en tres maneras. Ca o son libres, o siervos o aforrados aque llaman en latin libertos". Ibídem, partida quarta, tit. XXIII.
} 
indicaba en el testamento que el esclavo sería libre con la condición que le pasara una determinada cantidad de dinero a sus herederos, o que les ayudara en ciertos menesteres de trabajo. De esta forma asumía una condición intermedia entre la esclavitud y la libertad, llamada statuliber. Éste tenía la facultad de demandar al heredero si se negaba a cumplir lo estipulado en el testamento. En este tipo de manumisión el amo debía claramente indicar la condición y el momento en que el esclavo sería declarado libre ${ }^{26}$. Pero en el derecho romano y en las Siete Partidas los juristas habían establecido que, cada vez que la intención del testador resultara oscura o ambigua, el testamento debía ser interpretado a favor de la libertad del esclavo. Entre las normas de las Siete Partidas, en las que aparece el favor libertatis, considero importante mencionar la que regulaba la condición de los hijos de esclavas manumitidas en estado de gravidez. Esa norma establecía que, tanto la esclava como el niño por nacer, serían formalmente libres al término previsto por el amo en el acto de manumisión y no en el momento en que se ejecutaban dichas disposiciones ${ }^{27}$.

El favor libertatis estaba previsto ante la existencia de lazos de sangre o de un cierto respeto entre el amo y el esclavo a manumitir; si bien para algunos tipos de manumisión el amo debía tener por lo menos veinte años, en caso que el esclavo tuviera con él lazos de sangre, o fuera su maestro o quien lo había criado, el amo podía disponer la manumisión desde el momento en que cumpliera los 14 años (partida quarta, tit. XXII, Ley I).

Muchos investigadores se han preguntado si los esclavos de las colonias españolas recibieron un tratamento mejor, con respecto a los de otras colonias. Tannebaum sostiene que la esclavitud en las colonias norteamericanas fue más dura, debido al hecho que no fué mitigada por las construmbres e instituciones del viejo mundo, que sobrevivieron a veces en la América hispanica ${ }^{28}$. Por otro lado, Davis subraya la importancia de los elementos de continuidad entre la esclavitud antigua y las esclavitudes de las diferentes colonias americanas, poniendo de relieve el elemento comun de la deshumanización del esclavo ${ }^{29}$. Pero Davis evidencia también una diferencia importante entre la esclavitud como idea y como situación legal y la esclavitud como institución y producto real de las relaciones entre amos y esclavos en diferentes contextos. La esclavitud como idea estuvo menos sujeta a variaciones regionales y a cambios historicos de la institución esclavista ${ }^{30}$.

\footnotetext{
${ }^{26}$ Cfr. Alan Watson, Roman Slave Law (Baltimore: The John Hopkins University Press, 1987), 25 y 34; Volterra, Istituzioni di diritto, 760-762.

27 "Demientre que estoviere la criatura en el vientre de su madre, toda cosa que se faga, o se diga, a pro della aprovechase ende, bien assi como si fuesse nascida: mas lo que fuesse dicho o fecho a daño de su persona, o de sus cosas, non le empesce. E porende si el Señor de alguna sierva preñada mandasse a su heredero, o diesse poder a otro que la aforrasse a cierto plazo, si el otro non la fiziesse libre aquel dia que el mando estando esperando maliciosamente, que nasciesse aquella criatura: porque fuesse sierva: dixeron los sabios antiguos, que fizieron las leyes que desde el dia del plazo en adelante, son libres, tan bien la madre, como la criatura que della nasciesse". Las Siete Partidas, partida quarta, tit. XXIII, ley III.

${ }^{28}$ Frank Tannenbaum, Slave and Citizen: The Negro in the Americas (Nueva York: A. A. Knopf, 1947).

${ }^{29}$ David Brion, The Problem of Slavery in Western Culture (Nueva York: Oxford University Press, 1988).

${ }^{30}$ Ibídem, 30
} 
En este trabajo no quiero adentrarme en el debate sobre la benignidad o crueldad de las diferentes sociedades esclavistas, pero sería interesante entender por qué, segun las normas que hemos analizado, el derecho romano y el derecho castellano medieval suministraron a los esclavos de las colonias españolas más amplias posibilidades de manumisión. Watson sostiene que eso fue posible porque en la América española se aplicaron leyes que habían sido elaboradas en sociedades donde la esclavitud no estaba reservada a determinados grupos sociales o raciales, sino donde, al menos teóricamente, cualquiera podía caer esclavo, ya fuera por ser prisionero de guerra o por deudas ${ }^{31}$. En las Siete Partidas la esclavitud había sido una condición vil y despreciable, extraña al estado natural:

Servidumbre, es la mas vil, e la mas despreciada cosa, que entre los omes puede ser. Porque el ome, que es la mas noble e libre criatura, entre todas las otra criaturas, que dios fizo, se torna por ella en poder de otro: de guisa que pueden fazer delo que quisiere, como de otro fue aver bivo o muerto ${ }^{32}$.

En la sociedad hispanoamericana, donde las distinciones de estatus coexistieron junto a las raciales y en la que un grupo racial específico fue designado a ser esclavo, estas normas, según los juristas de la época, ofrecían posibilidades de liberación demasiado amplias ${ }^{33}$. Esto aparece en las numerosas cédulas producidas en el curso de tres siglos, en las que se intentaron poner limites a las manumisiones, a menudo sin éxito. Mientras Rafaela y su esposo luchaban por su libertad, en España se redactaban los Códigos Negros, que habrían de prohibir a los esclavos contratar libremente su manumisión y a los amos poderles manumitir por voluntad propia, sin antes haber obtenido el parecer favorable del gobernador y del procurador general $^{34}$. La libertad, que en la Siete Partidas era considerada la condición natural de cada ser humano, se estaba convirtiendo, para los esclavos americanos, en una condición extraordinaria:

Si es la libertad para el esclavo la recompensa mayor que puede imaginarse, serán pocas las acciones dignas por sí solas de ella ${ }^{35}$.

Los esclavos, nunca más iban a ser considerados hombres que habían experimentado, durante sus vidas, una vil condición, sino negros supersticiosos, fanáticos y peligrosos que debían ser educados en el respeto y la subordinación a los blancos:

\footnotetext{
${ }^{31}$ Cfr. Watson, Roman, 4; Slave Law, 23-24.

${ }^{32}$ Las siete partidas, partida cuarta, tit V.

${ }^{33}$ Watson, Roman, 30.

${ }^{34}$ La historiografía americanista ha reunido, bajo la definición de Códigos Negros dos códigos y una Instrucción emitidos, entre el 1768 y el 1789 (Código Negro de Santo Domingo, Código Carolino e Instrucción sobre educación, trato y ocupaciones de los esclavos) y el Code Noir de la Luisiana, cedida a España en el 1762. Para un estudio profundizado de los Códigos Negros, véase Manuel Lucena, Los Códigos Negros de la América española (Alcalá: Universidad de Alcalá; Ediciones Unesco, 1996).

${ }^{35}$ Código de legislación para el gobierno moral, político y económico de los negros de la isla Española (Código Negro Carolino), capítulo 19: "De las libertades de los esclavos".
} 
Son además estos africanos supersticiosis y fanáticos, muchos fáciles a la seducción y a la venganza, e inclinados naturalmente a las artes venenosas, de que han usado peligrosamente en las colonias extranjeras; ...se hace necesario desarraigar de su corazón tan vehementes nativas inclinaciones, sustituyendo en él las benéficas de la lealtad al soberano, del amor a la nación española, del reconocimiento y gratitud a sus amos, de la subordinación a los blancos $[\ldots]^{36}$.

Mientras las normas jurídicas permanecieron más bien inalteradas hasta finales del siglo XVIII, la percepción de la esclavitud había cambiado desde hacía tiempo, como también la definición de libres y esclavos, que dependía, más que de los aspectos jurídicos, de otros factores derivados de la raza, del honor y de las relaciones de poder presentes en la sociedad colonial. Por lo tanto, para establecer si Rafaela era libre o esclava no era suficiente interpretar una cláusula de manumisión ambigua. Era necesario, para los contendientes, adentrarse en la sociedad cartagenera y demostrar que Rafaela era libre o esclava a partir de su relación con Alberto Martínez y su familia.

\section{Libres y esclavos en la familia colonial}

Los contendientes sostenían que Rafaela era libre o esclava tratando además de interpretar la naturaleza de su relación con Alberto Martínez (una relación amo-esclava, o una relación padrehija), y el tipo de tratamiento que la familia Martínez le había dado. Lorenzo Gómez defendía la tesis de que su mujer era formalmente libre, buscando en los sentimientos paternos de don Alberto las razones que lo habían inducido a insertar en el testamento la cláusula y, según él, a dejarla libre desde el momento de su muerte. Le había contestado a don Miguel, quien sostenía, no obstante, la ilegitimidad de la manumisión de Rafaela, ya que violaba el derecho sucesorio entonces vigente, de esta manera:

[...] cesa la discusión en punto de si tuvo o no cabida la libertad en el quinto de los bienes del testador, y aún en el todo, pues siendo su hija por derecho alguno debió tenerla por su esclava ni dejarla por tal, y ni aún siquiera con la consabida pensión de servir a su madrasta por su vida, sino sólo mientras tomase estado, con el santo fin de su buena educación, empero estando como está desposada conmigo sobre que la recta administración de justicia de V.S. determinara lo que mas conforme fuese $^{37}$.

La argumentación que sostiene la tesis, tan opuesta a lo previsto por las Siete Partidas, según la cual Rafaela como hija de don Alberto era libre desde su nacimiento, será profundizada a

\footnotetext{
${ }^{36}$ Código de legislación, capítulo 2: "De la educación y buenas costumbres".

37 "De autos que ha seguido", fl. 419v. En cuanto a la tesis de don Miguel sobre la presunta violación del derecho sucesorio, él se refería a una de las Leyes de Toro que establecía que el testador podía libremente disponer de no más de la quinta parte de los bienes de los cuales era propietario, mientras el resto debía ser heredado por la mujer y los hijos. Según don Miguel, el valor económico atribuible a Rafaela superaba esa quinta parte, además que Rafaela, adquirida después del matrimonio de Dionicia y Alberto, no pertenecía exclusivamente a este último, sino también a su consorte, por lo que él no habría podido concederle la libertad sin el consenso de Dionicia.
} 
continuación. De la réplica de Lorenzo es interesante destacar las consideraciones sobre la obligación de servir a Dionicia. Según él, don Alberto no habría podido obligar a Rafaela a servir a su mujer después de la muerte de ésta, sino sólo hasta la emancipación de Rafaela, por lo que, casándose, se hubiera alejado del dominio de Dionicia. Si tal dominio debía cesar con dicha emancipación, entonces era diferente del que normalmente un amo ejercitaba sobre una esclava, ya que éste no concluía con su matrimonio.

Según las afirmaciones de ambos contendientes y de las personas que se presentaron en calidad de testigos, Rafaela había recibido de la familia Martínez un tratamiento respetuoso, que le había permitido organizar de manera autónoma los trabajos domésticos que le habían sido asignados sin sufrir los castigos reservados a otros esclavos. Mientras Lorenzo percivía en ese tratamiento que Rafaela era considerada por Alberto y Dionicia como una hija, Miguel Martínez sostenía que ese era el tratamiento normal reservado a los esclavos. Tratar bien y educar a sus esclavos era el deber de cada amo, lo cual no significaba que no fueran considerados como tales. El buen tratamiento no les adjudicaba la libertad, si no los amos hubiesen tenido que castigar a los esclavos aún cuando no fuera necesario:

[...] hombres justos mantienen en cautiverio a los negros tratándolos bien, enseñándoles la doctrina de nuestra Santa Religión, sirviéndose de ellos y vendiéndolos quando les conviene sin que por no darles la libertad o en vida o en muerte sino deben ofendan a Dios [...] si por sólo el buen trato que muchos amos dan a sus esclavos porque les sirven bien se hubieran por eso de libertad de ser sus siervos pocos esclavos hubiera o se vieran precisados los amos por no perder su dinero a castigarlos aunque no les diesen para ello motivo ${ }^{38}$.

La idea que los esclavos debían ser bien tratados y educados tenía raíces profundas en el mundo hispanoamericano. Ya las Siete Partidas, que reconocían la libertad como condición natural de todos los hombres, habían puesto límites, si bien mínimos, al poder de los amos. En las cédulas emitidas por la corona española para las Indias en los siglos XVI y XVIII, confrontar los abusos de los amos y los maltratos de los esclavos fueron exigencias dictadas por la necesidad de prevenir desórdenes y rebeliones. Asimismo era considerado reprochable maltratar a los esclavos, ya que eran cristianos ${ }^{39}$. Las numerosas cédulas que los reyes emitieron con tal objetivo revelaban en realidad la frecuencia con que los esclavos eran maltratados, pero pudieron ser usadas por los que, como Miguel Martínez, sostenían que el buen tratamiento no conducía a la libertad.

Para defender la libertad de su mujer, Lorenzo no podía sencillamente decir que la familia Martínez la había tratado bien, sino que debía usar términos que le permitieran demostrar de manera inequívoca que su mujer había sido considerada y tratada como una persona libre. He aquí lo que destaca de las preguntas que planteara a sus testigos:

\footnotetext{
${ }^{38}$ Ibídem, fl. 447r y 469v.

${ }^{39}$ Una lista completa de las leyes que regulaban la condición de los esclavos y su relación con los dueños ha sido recopilada en Manuel Lucena, Leyes para esclavos.
} 
Suplico a V.S. se sirva mandar que con contraria citación sean examinados los testigos que presentaré de aquel vecindario residente en el día en esta ciudad al tema de los siguientes interrogados. Primeramente por el conocimiento de las partes noticias de esta causa, edad y generales de la ley. Si saben y les consta por ser cosa muy sabida en aquel sitio de San Benito que Rafaela Martínez mi esposa es hija bastarda de Alberto Martínez padre legitimo de adverso litigante Don Miguel Martínez. Y si por ello la han tratado siempre antes de este litis con la estimación correspondiente en su casa. [...] si asimismo saben que por dicha paternidad el contenido Alberto Martínez la dejó libre en su testamento cuya cláusula certificada presentada tengo (a la que pido se remitan con sola la pensión de servir por su vida a Dionicia Calbo esposa del Alberto y madrasta de la Rafaela) explanando si han llegado a concebir que esto fue para la mejor educación y sugección de dicha Rafaela por haber estado en aquel tiempo con pocos años y sin haber tomado estado $[\ldots]^{40}$

La estimación reconocida a Rafaela era lo que permitía a Lorenzo sostener que el tratamiento reservado a su mujer era el mismo que a los demás miembros de la familia Martínez. Pero ¿podía este tratamiento excluir a Rafaela de la condición de esclava?

Para entendender el significado atribuido a un tratamiento de estimación es útil confrontar las preguntas de Lorenzo con las de don Miguel a sus testigos y las respuestas que fueron suministradas a ambos contendientes. Las preguntas de don Miguel revelan aspectos de cómo él concebía la relación amo-esclavo, según la cual éstos últimos no debían ser castigados arbitrariamente y los amos tenían el deber de suministrarle una adecuada educación religiosa:

[...] se ha de servir V.S. de mandar que los testigos que presentase con el juramento acostumbrado digan si conocen a las partes que litigan. Si tienen noticia de este pleito, qué edad cuentan, y si les tocan las generales de la ley. Si saben que mi madre, alguno de mis hermanos y yo hallamos tratado con crueldad a Rafaela Antonia Martínez Calbo mujer del Gómez castigándola en las ocasiones en que para ello haya dado motivo de suerte que la aspereza con que se haya tratado fuese suficiente para hacerle intolerable la esclavitud en que está. Si les consta no se le haya enseñado a ella y a sus hijas la doctrina cristiana, y lo demás que es necesario para salvarse, o si por el contrario saben que con ella y los demás de la familia, asi se ejecuta en el sitio de San Benito, llendo a cumplir con el precepto de la misa a San Stanislao, en donde sólo hay Iglesias, cuando los arroyos y aguas no lo impiden y anualmente con el precepto de la confesión y comunión, sin que jamás hayan oido decir haber fijado a alguno de los domesticos en la tablilla por haber faltado $^{41}$.

\footnotetext{
40 "De autos que ha seguido", fl. 422v y 423 r.

${ }^{41}$ Ibídem, fl. 425v y 426r.
} 
Tres de los testigos de Lorenzo, al responder a sus preguntas, habían sostenido que Rafaela era tratada con estimación, y habían dado a entender que ello era consecuencia del lazo de sangre que existía entre ella y don Alberto ${ }^{42}$.

Esas respuestas, por sí solas, no permiten comprender si una persona tratada con estima pueda considerarse esclava. Pero las respuestas de los testigos de Don Miguel valoran la hipótesis de que el tratamiento de estimación excluyera la condición de esclavitud. Los testigos de don Miguel tenían que responder a preguntas concernientes al buen tratamiento reservado a Rafaela, pero las respuestas de algunos lo describieron como un tratamiento de estimación, evidenciando así una discrepancia en la percepción de la esclavitud:

[...] a la contenida Rafaela la tratan todos los de la familia con estimación, y sin castigarla aunque de lugar a ello porque la ven como a hija del padre del don Miguel $^{43}$.

[...] la han tratado con particular estimación, y no como a esclava, de forma que aunque haya dado motivo para castigarla lo han dispensado contentándose únicamente con una corta reprimenda ${ }^{44}$.

Este último testimonio es muy interesante ya que parece revelar la incompatibilidad entre el tratamiento de estima y la condición de esclavo. ¿Es posible sostener que el tratamiento de estimación excluyera, para Rafaela, la condición de esclavitud?

Habian factores que podían indicar la percepción de libres y esclavos en la realidad social hispanoamericana y, en el caso específico de Rafaela, entre una esclava de origen africano y sus amos blancos. El desprecio hacia los trabajos manuales era común en toda persona que se considerara blanca, fuera un rico comerciante o uno que viviera en la miseria. En Cartagena, muchas personas llegadas de España con la esperanza de mejorar su condición social, vivían en situaciones de extremo malestar, a causa del rechazo a ejercer trabajos manuales. Mientras que unos pocos blancos, europeos y criollos, llevaban el poder político y económico y se dedicaban al comercio o eran terratenientes, los trabajos artesanales estaban ocupados por una multitud perteneciente a las castas, que conducían una vida modesta o decididamente pobre. A los esclavos les estaban reservados los trabajos domésticos o los trabajos a jornal en el puerto o en

\footnotetext{
42 “[...] ha oido comunemente así en dicho San Stanislao como en San Benito que Rafaela Martínez mujer del que lo presenta es hija bastarda de Alberto Martínez en cuya casa habitó hasta que se desposó y vió que la trató con estimación correspondiente como a tal su hija”, "[...] Rafaela Martínez mujer del que le presenta es hija bastarda de Alberto por que así se lo aseguró Geronimo Martínez cual hijo lexitimo de Alberto despues del fallecimiento de este y la mujer del que declara que fue criada en la casa del contenido Alberto que fue su padrino de bautismo ademas de ser público y notorio en el sitio de San Benito, y haber visto el testigo que la trataria así el Alberto su mujer e hijos como tal dándole estimación[...]" y "Rafaela Martínez mujer del que lo presenta es hija bastarda de Alberto Martínez padre de Don Miguel, en cuia casa la vio estar y tratar como tal con bastante estimación[...]”. Ibídem, fls. 423v, 424r, $424 \mathrm{v}$ y $425 \mathrm{r}$.

${ }^{43}$ Ibídem, fl. 426v.

${ }^{44}$ Ibídem, fl. 427r.
} 
las calles de la ciudad. Estos trabajos eran tan despreciados que a menudo también los esclavos que lograban ser libres, compraban a su vez uno o más esclavos para enviarlos a trabajar ${ }^{45}$.

En los testimonios sobre la vida de Rafaela salen a relucir algunas consideraciones sobre los trabajos que tuvo que hacer en la casa de los Martínez. Ellos revelan que si bien Rafaela realizaba trabajos domésticos, también disfrutaba, en relación a otros esclavos, de mucha autonomía en la ejecución de los mismos y no se le regañaba tan duramente por los errores $\operatorname{cometidos}^{46}$.

En la sociedad colonial era posible distinguir los esclavos negros de sus amos blancos, a traves del honor, que estaba conferido a estos últimos, pero no a los esclavos. Considerado la virtud principal de una persona y base de la estima que cada cual tenía de sí y de la que le atribuían los otros, el honor era un concepto complejo, cuyo significado podía ser reducido a dos aspectos principales. Por un lado designaba la dignidad exterior de una persona, derivada del estrato social al cual pertenecía y de la superioridad adquirida desde el nacimiento. Por el otro indicaba el reconocimiento que otras personas atribuían a la virtud y a la integridad moral de un individuo. El honor era por lo tanto un atributo de quien tenía orígenes nobles, pero su manifestación y su reafirmación debían provenir de una conducta virtuosa, que para los hombres significaba demostrar coraje y un comportamiento apropiado en la guerra, en las actividades económicas y en la vida pública, mientras que para las mujeres era una virtud en relación a la conducta sexual, que exigía la castidad antes del matrimonio y la fidelidad al cónyuge durante el mismo. El honor de las mujeres concernía también a los hombres, ya que el descubrimiento de relaciones sexuales ilícitas de las esposas, hijas y hermanas deshonraba a la familia completa. Esto convertía al honor en un valor extremadamente frágil y, por consecuencia, también las mujeres, que debían ser continuamente protegidas y controladas por los padres, esposos, hermanos y tíos, eran sujetos muy frágiles ${ }^{47}$.

El honor estaba estrechamente vinculado a la limpieza de sangre, pero a finales del período colonial estos dos valores con frecuencia entraban en conflicto a causa del proceso de la mezcla racial. Un ejemplo frecuente emerge de los conflictos relacionados a la oposición de los padres a las decisiones matrimoniales de los hijos. Entre la elite blanca éstas debían realizarse teniendo en cuenta algunos valores que involucraban a toda la familia, entre otros, la igualdad racial. La raza se había convertido en un bien que debía ser protegido y esto había reforzado, respecto a

\footnotetext{
${ }^{45}$ En relación con la presencia de los esclavos en la sociedad cartagenera y de los trabajos que éstos ejercían véase Múnera, El fracaso, 94-95, Antonio de Ulloa, Viaje a la América meridional (1748; Madrid: Edición de Andrés Saumell, 1990), 78; Carmen Bernand, Negros esclavos, 5; Pablo Rodríguez, Sentimientos.

46 “[...] no he visto tratar mal a la Rafaela asi en castigo [...] y vestuario tratandola en todo con estimación y no como a esclava haciendo en su trabajo lo que a ella le parecía y quería" y "[...] aunque haya dado motivo para castigarla lo han dispensado contentandose unicamente con una corta reprención". "De autos que ha seguido", fls. 439r y 427r.

${ }^{47}$ Cfr. Patricia Seed, To Love, Honor and Obey in Colonial Mexico. Conflicts over Marriage Choice, 1574-1821 (Stanford: Stanford University Press, 1988), 61-62, 166-169. Para un estudio profundizado de las relaciones entre honor, raza y género en relación con los discursos de esclavitud y las estrategias de libertad, véase María E. Chaves, Honor y Libertad. Discursos y recursos en la estrategia de libertad de una mujer esclava (Guayaquil a fines del periodo colonial) (Gotemburgo: Universidad de Gotemburgo, 2001), 147-182.
} 
los siglos precedentes, el poder de los padres sobre los hijos, por lo que jurídicamente también se sancionaban los matrimonios desiguales ${ }^{48}$. Los conflictos entre raza y honor superaban el ámbito privado y llegaban a ser visibles cuando los jóvenes con intenciones de casarse trataban de forzar la oposición de los padres con relaciones sexuales antes del matrimonio. La pérdida de la virginidad de las muchachas a menudo inducía a los padres a aceptar la celebración del matrimonio, pero cuando la relación ocurría con alguien de una raza inferior no siempre aceptaban un matrimonio reparador y, por lo contrario, se dirigían a las autoridades, exigiendo justicia $^{49}$. Estos conflictos permiten entender cómo raza y honor otorgan licencia al padre de ejercer un amplio poder sobre todas las personas que le eran subordinadas. Con el objetivo de proteger el honor y la limpieza de sangre, él tenía la facultad de controlar la vida de su mujer y la de sus hijos e imponer su voluntad en momentos importantes de sus vida.

Al mismo tiempo estos valores le permitían, como amo, ejercer un poder mucho más amplio sobre sus esclavos y esclavas, ya que no poseían limpieza de sangre ni honor. En la sociedad hispanoamericana fueron, de hecho, frecuentes los discursos que definían a los esclavos como sujetos exentos de la capacidad de poseer y sentir honor. Algunos de los amos los consideraban muertos civiles, colocados fuera del cuerpo social y del gobierno político, por lo tanto indignos de honor y de estimación. La falta de honor era lo que permitía a los amos ejercer su dominio, de lo contrario no hubieran podido someter, ni castigar a sus esclavos, por lo tanto cesaría la institución misma de la esclavitud ${ }^{50}$. El análisis de la correspondencia entre las autoridades coloniales y entre éstas y el Consejo de Indias puede revelar como los discursos que los definían sujetos carentes de honor inducían a los amos y a los estamentos políticos y religiosos a percibir a los esclavos y, más en general, a los negros y mulatos, como personas ociosas y proclives a satisfacer únicamente su sexualidad ${ }^{51}$.

Raza y honor representaban probablemente los factores de exclusión e inclusión de Rafaela en la familia Martínez. La raza era el elemento que la diferenciaba de sus hermanastros y lo que le había impedido entrar a formar parte de la familia con pleno derecho. No obstante, el hecho de haber sido criada y educada en la casa de Alberto y Dionicia y el haber recibido un tratamiento de estima, revela en cierta medida su inclusión en el ámbito familiar.

\footnotetext{
${ }^{48}$ Véase la "Pragmática sanción para evitar el abuso de contraer matrimonios desiguales" de 23 marzo 1776, en Lucena, Leyes para esclavos.

${ }^{49}$ Cfr. Pablo Rodríguez, Seducción, amancebamiento y abandono en la Colonia (Bogotá: Fundación Simón y Lola Guberek, 1991), 56-57.

${ }^{50}$ Cfr. María E. Chaves, "Slave Women's Strategies for Freedom and the Late Spanish Colonial State", en Maxine Moluneux y Elizabeth Dore, ed., Hidden Histories of Gender and State in Latin America (Durham: Duke University Press, 2000), 108-1266.

51 Véase la "Representación del gobernador de Popayán al Virrey del Nuevo Reino de Granada sobre los inconvenientes de los capítulos octavo y decimotercero de la Instrucción de 1789": "[...] se les observa una propensión innata al ocio y que como hombres separados de los sentimientos de honor y de los estimulos del buen nombre, dirigen toda su atención a satisfacer la sexualidad por cuantos caminos les brinda la ocasión”. Manuel Lucena, Sangre sobre piel negra (Quito: Ediciones Abya-Yala, 1994), 121 y la Carta del obispo de Cartagena al Consejo de Indias: “[...] la depravada inclinación de esta gente que se aprovecha de las ocasiones para ejecutar lo que aún en casas de amos celosos frequentemente ejecutan, buscando ellas mismas las ocasiones [...] esta gente se arroja ciegamente a la culpa, y para excusar la pena, busca medios para abortar". "Expediente sobre el maltrato".
} 
Sin embargo, la condición de estima que se le había atribuido no era suficiente para determinar la condición legal de libre, que sí dependía de factores jurídicos, es decir, de lo establecido en la cláusula de manumisión. Uno de los testigos de don Miguel había expresado con mucha claridad cómo el tratamiento de estimación no garantizaba, por si mismo, la condición jurídica de libre para Rafaela, evidenciando una profunda discrepancia entre el estatus legal y su condición material:

Certifico en la mas bastante forma que puedo y debo y por derecho me es permitido ante los señores jueces y justicia de S.M. que la presente vieren que es cierto que ha el tiempo de diez y ocho años que conosco a doña Dionicia Calbo y a toda su familia y que asimismo conozco a Lorenzo Gómez moreno libre marido de Rafaela Martínez a la que he conocido en el dicho término de los años citados por esclava de la Doña Dionicia a quien me consta por cierto le tiene puesto pleito el Lorenzo pretendiendo la libertad de la citada su mujer e hijas con quien por parte ninguna me tocan las generales de la ley siendo cierto igualmente que en los años citados que ha que conosco a la citada doña Dionicia Calbo y a toda su familia de trato vista y comunicación no he visto tratar mal a la Rafaela asi en castigo (...) y vestuario tratándola en todo con estimación y no como a esclava haciendo en su trabajo lo que a ella le parecía y quería ${ }^{52}$.

\section{Antiguos valores}

Si bien contendientes y testigos habían apuntado interpretaciones diferentes en cuanto a la condición de Rafaela en la familia Martínez, se habían mostrado de acuerdo en afirmar que el padre era don Alberto. En el curso del procedimiento Lorenzo había afirmado que el contenido de la cláusula de manumisión no influía sobre lo que él sostenía que era la condición real de su mujer, ya que, como hija del propio amo, Rafaela hubiese tenido que poseer la condición de libre desde su nacimiento:

Y concluye al pronunciamiento imperiado a mi favor lo segundo cual es el ser mi consorte hija bastarda de Alberto Martínez su amo y mi suegro legítimo padre del adverso mi cuñado lo que extra de que no se ha negado de contrario lo he probado puntualmente en el probatorio artículo con tres testigos contestes y aún con los mismos de la de contrario producida quienes contestando a su respectivo interrogatorio aseveran el particular buen tratamiento que se le ha dado a la Rafaela mi consorte indicante por cierto según las palabras que cada testigo expende de la paternidad de su difunto amo llegando aún a exponerlo con voces claras Dr. Matias Roca y Narvaez a la hoja veinte y ocho vuelta a cuya vista no queda resquicio que favorecer pueda la injusta contraria pretención pues por mas quiera aparentar que

\footnotetext{
${ }^{52}$ Testimonio de don Marcos Ortega, "De autos que ha seguido", fl. 439r.
} 
el hijo del amo es esclavo no solo es inaudita tal proposición sino que aún pasa a ser escandalosa $[\ldots]^{53}$.

En relación a las cuestiones analizadas anteriormente, en las que fueron suministradas diferentes interpretaciones sobre la condición de Rafaela, Lorenzo había iniciado un discurso que menoscabara uno de los fundamentos de la esclavitud, la transmisión de la condición servil. Las Siete Partidas habían establecido que los hijos heredaran de la madre la condición jurídica de esclavos (Partida cuarta, tit. XXI, Ley II). Rafaela era oficialmente hija de una esclava y de un negro libre. Aún reconociendo que su verdadero padre era don Alberto, don Miguel afirmaba que no podía ser libre, ya que sólo el matrimonio del amo con su esclava habría podido lograr que la esclava y sus hijos fueran libres:

Ni debe valer el que fue la Rafaela hija bastarda de mi padre pues es común doctrina de clásicos A.A. juzgados en derecho que los hijos del amo habidos en concubinato con sus esclavas son esclavos de su propio padre como lo es la madre a la que privan de poder reclamar a la libertad, aunque por el carnal acto se haga su amo con ella un cuerpo; porque no la hizo con el su igual, a causa de faltar el matrimonio del cual es esto propio ${ }^{54}$.

¿Con qué argumentos podía rebatir Lorenzo una de las normas sobre las que se basaba la esclavitud hispanoamericana? Hojeando el expediente relacionado con la manumisión de Rafaela, surgen consideraciones acerca de las violaciones y los abusos que los amos cometían sobre sus esclavas, no sólo para satisfacer sus deseos, sino también para generar nuevos esclavos:

[...] si se permitiera cosa tal [Lorenzo se refería a la eventualidad que el hijo del amo pudiera ser esclavo] sería dar ansa los mismos jueces a que los mal inclinados $\mathrm{y}$ codiciosos sin atender ni al santo temor de Dios ni a la natural afección observada y practicada aún entre los irracionales que tienen a sus propios hijos aún siendo monstruos y no de una misma especie usasen de rienda suelta de sus esclavas con el pugnible fin no solo de saciar su concupisencia si también y aún mas principalmente de aumentar el caudal multiplicando esclavos con su propia sangre lo que es repugnante en todos los derechos y por ello todos los señores jueces vigilan celan y castigan excesos tales y por ello para que sirva de freno a los que fueren tales viciosos y codiciosos no faltan legales disposiciones que favorezcan no sólo al hijo del amo para ser declarado por libre sino aún a la que justificare que el amo la ha usado para con este salutífero remedio impedir el que los amos [...] quieran absolutamente usar de sus esclavas todo lo que se ha visto practicado en esta propia ciudad en diferentes ocasiones ${ }^{55}$.

\footnotetext{
${ }^{53}$ Ibídem, fls. 441r y 441v.

54 "De autos que ha seguido", fls. 420r y 420v.

${ }^{55}$ Ibídem, fl. 441v.
} 
Las disposiciones legales de las que hablaba Lorenzo, se referían probablemente a una propuesta hecha en el 1752 por el gobernador de Cartagena al Consejo de Indias que preveía que, en caso de abusos y maltratos a esclavas por sus propios amos, éstas quedasen libres ${ }^{56}$.

Si bien no sabemos cómo fue acogida esa propuesta por el Consejo de Indias, probablemente habría inducido a muchas esclavas a reclamar la libertad. Esto explica sin embargo, sólo en parte, las consideraciones de Lorenzo. Pero sobretodo, no explica cómo su tesis pudiera ser acogida plenamente en la sentencia emitida en primera instancia. El teniente del gobernador, don González de Sala, al declarar libre a Rafaela había afirmado:

Vistos dijo su señoria que declaraba y declaró por libre de toda esclavitud a Rafaela Antonia Martínez mujer de Lorenzo Gómez como hija de Alberto Martínez quien no pudo gravarla con la servidumbre de servir a su mujer Dionicia Calvo durante su vida por no poder el padre tener a sus hijos por esclavos ni a sus nietos y por consiguiente se declaran por libres los hijos de dicha Rafaela habidos del matrimonio con el dicho Lorenzo Gómez y se condena en todas las costas a la dicha Dionicia y a su hijo Don Miguel de justa tasación y por este su auto difinitivamente juzgando asi lo proveo mando y firmo el señor licenciado Don Joseph Gozalbez de abogado de sala de los Reales Consejos teniente de gobernador y auditor de guerra de esta plaza y provincia por S.M. en veinte y siete dias del mes de octubre de mil setecientos sesenta y ocho ${ }^{57}$.

Esta sentencia confirmaba que los discursos de Lorenzo y su defensor no estaban aislados y que, probablemente, algunos cambios acaecian en la sociedad cartagenera.

Releyendo las cartas enviadas por Lorenzo es posible percibir entre líneas una serie de consideraciones vinculadas a los antiguos valores del honor y del derecho de sangre. Al tener "su misma sangre" los hijos de los amos heredaban del padre virtudes como el honor y la nobleza, por lo que dada su naturaleza, era inaudito y hasta escandaloso que fueran esclavos. Para entender mejor estas consideraciones es necesario leer las palabras pronunciadas en la Audiencia de Santafé, por el procurador de pobres Blas de Valenzuela a favor de la libertad de Rafaela.

Después de recursos y anulaciones de las sentencias precedentes, el caso de Rafaela fue discutido en la Audiencia. El procurador de don Miguel había vuelto a proponer las tesis ya vistas anteriormente, según las cuales la cláusula testamentaria era condicional y violaba las Leyes de Toro, pero esta vez negaba rotundamente que Rafaela fuera hija de don Alberto ${ }^{58}$.

\footnotetext{
56 "Como algunos amos se mezclen con las propias esclavas quitandoles su honor, sería conveniente para obviar estos pecados, y la continuación que se sigue de un amancebamiento, proponer al Rey se sirviese mandar que por este solo hecho quedase la esclava libre, con lo que se contendrían algunos por su interes, no conteniendose por la ofensa de Dios". "Expediente sobre el maltrato".

57 "De autos que ha seguido", fl. 448v.

58 “[...] es una suposición enteramente falcisima, el que la citada Rafaela sea hija del dicho Alberto Martínez”. Ibídem, fl. 479v.
} 
Muy al contrario, el procurador de pobres había elaborado su discurso de libertad a partir de la paternidad de don Alberto. Rafaela debía ser libre "por derecho de sangre", ya que:

[...] según mirablemente funda [...] el más célebre expositor de las Leyes de Toro el hijo sea de la naturaleza que fuere, es hábil y capaz de suceder en todo lo que a tal derecho es concerniente, que no sean bienes, extendiéndose hasta la hidalguía, y nobleza con la Ley de Partida, que habla, y la concede aún en caso de ser la madre de vil condición ${ }^{59}$.

Según Valenzuelas, el derecho castellano permitía a todo hijo heredar del padre la nobleza aún cuando la madre fuera de condición humilde, ya que a través de la sangre, el hijo heredaba del padre su misma naturaleza. También Rafaela había heredado naturalmente la nobleza de su padre, pero su condición de esclava le había impedido hasta entonces poder disfrutar de los beneficios de tal herencia:

[...] es aún más fuerte el motivo que hay para que goce Rafaela de su libertad, que lo fuera para disfrutar nobleza, la que concediéndose por el mismo derecho, no hay que dudar en que aquella por identidad y mayoridad de razón lo es también concedida. Esta misma se encuentra en el hijo del propio amo respeto de la esclava, que casa con su señor la cual adquiere por el mismo hecho... porque el señor por el matrimonio hizo semejante e igual a si la sierva; y no teniendo mayor eficacia y vigor esta igualdad, que la que por naturaleza tiene el hijo con el padre claro es que a la manera, que la esclava consigue la libertad por el matrimonio también el otro por la filiación ${ }^{60}$.

Si el derecho establecía que casándose con su amo, la esclava adquiría la libertad y su misma condición, con mayor razón Rafaela debía ser libre porque era similar al padre no por derecho, sino por naturaleza. El procurador de pobres había basado su discurso sobre la contradicción entre naturaleza y derecho, que en un momento de profundos cambios sociales, había asumido una nueva connotación. Como había sido explicado al promotor fiscal de la diócesis cartagenera, en cuanto imitador de la naturaleza, el derecho no la podía contrastar y, por lo tanto, no podía impedir que Rafaela disfrutara la nobleza que le había transmitido el padre.

El 22 de febrero de 1770 la Audiencia de Santafé reenviaba el caso de Rafaela al teniente del gobernador de Cartagena, ordenándole agregar a las actas la copia legal de la cláusula de manumisión y verificar si ésta se acordaba con el derecho vigente:

[...] en su consecuencia se devuelve el conocimiento de esta causa al actual teniente de gobernador, para que haciendo agregar a los autos, testimonio de la claúsula del testamento, su cuya disposición falleció Alberto Martínez con pie y cabeza, en que

\footnotetext{
${ }^{59}$ Ibídem, fl. 485r.

${ }^{60}$ Ibídem, fl. $485 \mathrm{v}$.
} 
trata de la libertad de Rafaela su esclava, y los inventarios y avalúos de los bienes que [...] por muerte de dicho Alberto, la sustancie y determine conforme a derecho, concediendo las apelaciones que se interpusieron para esta Real Audiencia. Y ejecútese sin embargo de súplica ${ }^{61}$.

\section{Conclusiones}

El expediente custodiado en el Archivo General de la Nación de Bogotá termina en este punto y no es posible saber si Rafaela logró finalmente su libertad. Sin embargo, el testimonio de su historia permite adentrarnos en una época en que la esclavitud estaba asumiendo nuevas connotaciones, como consecuencia de las dificultades que surgían en el esfuerzo para regularla usando normas jurídicas antiguas, ajenas al renovado contexto social.

Partiendo de la contraposición entre normas jurídicas y mutaciones sociales, he tratado de llevar una investigación que me permitiera perfilar los límites entre libres y esclavos. Jurídicamente, la situación del esclavo se definía por las relaciones de dominio y patria potestad que lo vinculaban al propio amo y que lo caracterizaban por la falta de personalidad jurídica. En la época en la que se elaboraron las Siete Partidas, la ausencia de distinciones raciales entre libres y esclavos permitió la formulación de leyes que humanizaron la figura del esclavo, reconociéndole algunos derechos anteriormente adjudicados sólo a personas libres. En tal contexto, también las posibilidades de manumisión fueron ampliadas. En la sociedad hispanoamericana la esclavitud había sido posteriormente transformada y destinada a las personas de origen africano. Adquirió entonces una connotación racial, por lo que el estatus social de los esclavos estuvo relacionado con su raza y al hecho de que fueran obligados a desarrollar actividades que otros grupos consideraban despreciables. En el contexto cartagenero de finales del siglo XVIII, en el que estaban presentes un considerable número de negros y mulatos jurídicamente libres pero obligados a una vida similar a la de los esclavos, los fuertes contrastes entre situación juridica y consideración social habían dificultado trazar distinciones: la consideración social atribuída a una persona podía no necesariamente coincidir con su estatus legal. En el caso de Rafaela esta tendencia había asumido una connotación extrema.

Por otro lado, al analizar la superposición de las relaciones amo-esclava y padre-hija, he tratado de entender qué diferencias permitían distinguir la vida de una esclava en relación a la de una persona libre dentro de la familia colonial. Según la regulación de la esclavitud en Hispanoamérica, la condición del esclavo se asimilaba a la de los hijos, ambas sujetas a la autoridad paterna. El poder que el señor ejercía sobre ellos no era de naturaleza diferente, sino que variaba en intensidad. Los datos a mi disposición evidencian cómo raza y honor fueron los dos elementos que permitieron diferenciar libres y esclavos en la familia y en la sociedad cartagenera. Como la raza, también el honor estaba vinculado a la limpieza de sangre, pero exigía además, de parte de aquellos que eran considerados dignos, una conducta apropiada.

\footnotetext{
${ }^{61}$ Ibídem, fl. 489r.
} 
En una situación de mestizaje racial, la doble naturaleza había llevado con frecuencia al honor a contradecir a la raza, hasta hacer irreconciliables los valores sobre los que se fundaba, hasta el momento, la sociedad colonial. También en el caso de Rafaela, resultado de una mezcla entre un blanco y una negra y educada en la familia del propio amo, estos dos valores habían entrado en conflicto y no podían por lo tanto ser usados para determinar su estatus.

Sin embargo, el procurador de pobres de la Audiencia de Santafé había descubierto otro valor más antiguo y sólido: la nobleza transmitida a Rafaela por sangre paterna. En este caso, como ya habíamos visto en la correspondencia entre el promotor fiscal de la diócesis de Cartagena y el Consejo de las Indias, una condición considerada natural entraba en contradicción con las normas jurídicas. Pero según las interpretaciones entonces vigentes, el derecho no podía oponerse a la naturaleza e impedir que Rafaela disfrutara de su propia nobleza.

\section{Bibliografía}

\section{Fuentes primarias}

"Baltasar Gómez de Liñan, promotor fiscal". Archivo General de Indias, Sevilla. Santa Fe, legajo 1044.

"De autos que ha seguido el negro Lorenzo Gómez con Don Miguel Martínez sobre libertad de su mujer Rafaela y dos hijos". Archivo General de la Nación, Bogotá. Fondo Negros Esclavos de Bolivar, Tomo 13.

"Expediente sobre el maltrato que dan los dueños de esclavos á estos en Cartagena y libertad en que dejan vivir á las esclavas". Archivo General de Indias, Sevilla. Santa Fe, legajo 1023.

"Prohibición de los bailes". Archivo General de Indias, Sevilla. Santa Fe, legajo 1044.

"Visita del Obispo de Cartagena de Yndias en todo su Obispado, 13 enero 1781". Archivo General de Indias, Sevilla. Santa Fe, legajo 1063.

\section{Fuentes secundarias}

Alvarsson, Jan-Åke, ed. Ethnicity in Latin America. Uppsala: CELAS, 1990.

Bermúdez, Agustín. "La abogacia de pobres en Indias". En Anuario de historia del derecho español. Tomo 50. Madrid: Ministerio de Justicia; CSIC, 1980.

Bernard, Carmen. Negros esclavos y libres en las ciudades hispanoamericanas. Madrid: Fundación Histórica Tavera, 2000.

Borja, Jaime H. "Sexualidad y cultura femenina en la Colonia. Prostitutas, hechiceras, sodomitas y otras transgresoras". En Magdala Velásquez, Catalina Reyes, Pablo Rodríguez. Las mujeres en la historia de Colombia, Vol. 2. Bogotá: Editorial Norma, 1995. 
Borrego, María del Carmen. "La conformación de una sociedad mestiza en la época de los Austrias 1540-1700". En Adolfo Meisel, ed. Historia económica y social del Caribe colombiano. Bogotá: Ediciones Uninorte, 1994.

Brion, David. The problem of Slavery in Western Culture. New York: Oxford University Press, 1988.

Chavez, María E. Honor y libertad. Discursos y recursos en la estrategía de libertad de una mujer esclava (Guayaquil a fines del periodo colonial). Gotemburgo: Universidad de Gotemburgo, 2001.

"Slave Women's Strategies for Freedom and the Late Spanish Colonial State". En Maxime Molyneux y Elizabeth Dore, ed. Hidden histories of gender and state in Latin America. Durham: Duke University Press, 2000.

De Solano, Francisco, coord. Estudios sobre la ciudad iberoamericana. Madrid: CSIC, 1983.

De Trazegnies, Fernando. Ciriaco de Urtecho: litigante por amor. Reflexiones sobre la polivalencia táctica del razonamiento jurídic. Lima: Pontificia Universidad Católica del Perú, 1989.

Dominguez, Antonio. "La esclavitud en Castilla durante la edad Moderna". Estudios de historia social de España, no. 2 (1952): 369-428.

Dougnac, Antonio. Manual de Historia del derecho indiano. México: Universidad Autónoma de México, 1994.

Gacto, Enrique, Juan A. Alejandre y José M. García. El derecho histórico de los pueblos de España. Madrid: Agisa, 1988.

Gálves, María Á. "Ilegítimad y matrimonio bajo el sistema colonial". En María T. López, coord. De la edad media a la moderna: mujeres, educación y familia en el ámbito rural y urbano. Malaga: Universidad de Malaga, 1999.

García, Concepción. "Sobre el ordenamiento juridico de la esclavitud en las Indias españolas". Anuario de historia del derecho español, no. 1 (1980).

González, Margarita. "El proceso de manumisión en Colombia". Cuadernos Colombianos, no. 2 (1974).

Gutierrez, Virginia. La familia en Colombia. Trasfondo histórico. 1963; reimpresión, Medellín: Editorial Universidad de Antioquia, 1997.

Herrera, Martha. Poder local, población y ordenamiento territorial el la Nueva Granada - Siglo XVIII. Bogotá: Archivo General de la Nación, 1996.

Jackson, Robert. "Race/Caste and the Creation and Meaning of Identity in the Colonial Spanish America". Revista de Indias, vol. 55 (1995).

Jaramillo, Jaime. Ensayos de historia social. La sociedad neogranadina. Bogotá: Tercer Mundo Editores 1989.

Kuethe, Allan J. "The Early Reforms of Charles III in the Viceroyalty of New Granada, 17501776". En Allan Kuethe, J.R. Fisher y Anthony McFarlane. Reform and Insurrection in Bourbon New Granada and Peru. Baton Rouge: Louisiana State University Press, 1990.

Las siete partidas del sabio rey don Alfonso $X$ glosadas por Gregorio López. Salamanca: Andrea de Portonariis, 1555. Edición facsimilar. Madrid: Boletín oficial del Estado, 1974. 
Lavrin, Asuncion, ed. Sexuality and Marriage in Colonial Latin America. Lincoln: University of Nebraska Press, 1989.

Lemaitre, Eduardo. Breve historia de Cartagena Medellín: Editorial Colina, 1993.

Lucena,Manuel. Sangre sobre piel negra.Quito: Ediciones Abya-Yala, 1994.

Los Códigos Negros de la América española. Alcalá: Universidad de Alcalá; Ediciones Unesco, 1996.

Leyes para esclavos. El ordinamiento jurídico sobre la condición, tratamiento, defensa y represión de los esclavos en las Colonias de la América española. Madrid: Fundación Histórica Tavera, 2000.

McFarlane, Anthony. Colombia before Independence: Economy, Society and Politics under Bourbon Rule. Cambrige: Cambridge University Press, 1993.

Mörner, Magnus. Race Mixture in the History of Latin America. Londres: Little Brown and Company, 1967.

Múnera, Alfonso. El fracaso de la nación. Región, clase y raza en el caribe colombiano (17171821). Bogotá: Banco de la República; El Áncora Editores, 1998.

"Ilegalidad y frontera 1770-1800". En Alfonso Meisel, ed. Historia económica y social del Caribe colombiano. Bogotá: Ediciones Uninorte, 1994.

Navarrete, María C. Historia social del negro en la colonia Cartagena, siglo XVII. Santiago de Cali: Editorial Universidad del Valle, 1995.

Ots Capdequi, José M. Estudios de historia del derecho español en las Indias. Bogotá: Editorial Minerva, 1940.

El estado español en las Indias México: FCE, 1941.

Pagden Anthony. La Caduta dell'uomo naturale. L'indiano d'America e le origini dell'etnologia comparata. Torino: Giulio Einaudi Editore, 1989.

Passerin, Alessandro. La dottrina del diritto naturale. Milano: Edizioni Comunità, 1954.

Phillips, William. "Continuity and Change in Western Slavery: Ancient to Modern Times". En ML Bush, ed. Serfdom and Slavery. Studies in Legal Bondage. Nueva York: Longman, 1996.

Pietschamann, Horst. El estado y su evolución al principio de la colonización española de América. México: FCE, 1989.

Real Academia Española. Diccionario de autoridades. 1737; Edición facsimilar. Madrid: Editorial Gredos, 1964.

Rodríguez, Pablo. Seducción, amancebamiento y abandono en la Colonia. Bogotá: Fundación Simón y Lola Guberek, 1991.

"El mundo colonial y las mujeres". En Magdala Velásquez, Catalina Reyes, Pablo Rodríguez. Las mujeres en la historia de Colombia, vol. 3. Bogotá: Editorial Noma, 1995.

Sentimientos y vida familiar en el Nuevo Reino de Granada Siglo XVIII. Bogotá: Editorial Ariel, 1997.

Seed, Patricia. To Love, Honor and Obey in Colonial Mexico. Conflicts over Marriage Choice, 1574-1821. Stanford: Stanford University Press, 1988. 
Serrera, Ramón M. "Sociedad Estamental y Sistema Colonial". En Antonio Annino, Luis Castro, Francois-Xavier Guerra. De los Imperios a las Naciones: Iberoamérica. Zaragoza: Ed. IberCaja, 1994.

Tannenbaum, Frank. Slave and Citizen: The Negro in the Americas. Nueva York: A.A. Knopf, 1947.

Tau, Victor. Casuismo y sistema. Buenos Aires: Instituto de Investigaciones del Derecho, 1992.

El poder de la costumbre: Estudios sobre el derecho consuetudinario en América hispana hasta la Emancipación. Madrid: Fundación Histórica Tavera, 2000.

Ulloa, Antonio de. Viaje a la América meridional.1748; Madrid: Edición de Andrés Saumell, 1990.

Volterra, Edoardo. Istituzioni di diritto privato romano. Roma: La Sapienza editrice, 1985.

Wade, Peter. Race and Ethnicity in Latin America. Londres: Pluto Press, 1997.

Watson, Alan. Roman Slave Law. Baltimore: The John Hopkins University Press, 1987. Slave law in the Americas. Georgia: University of Georgia Press, 1989.

Fecha de recepción del artículo: 27 de mayo de 2003

Fecha de aceptación: 22 de agosto 2003 